\title{
Government Policy to Accelerating Legal Certainty of Land Through Complete Systematic Land Registration (PTSL) (Studies in Kendal District Land Office)
}

\author{
Siti Sulistiyah ${ }^{1}$ and Umar Ma'ruf ${ }^{2}$
}

Abstract. Problems in this study: (1) How is the implementation of activities in the District Land Office PTSL Kendal? (2) How the Government's policy to accelerate the legal certainty Landrights through PTSL ?. The method used in this research is the method of approach to socio-legal research, consisting of socio research and legal research. The results of this study are: (1) Implementation PTSL in Kendal District Land Office begins by planning activities PTSL by the Head of the Kendal District Land Office with pre inventory candidate and potential participants. (2) Government policy in speeding up the legal certainty of land rights through PTSL is based in Kendal land that already has a certificate covering an area of 13834.46 hectares.

Suggestions in this study is consistent with the objectives of land registration is to provide certainty and legal protection to the rights holder, to reduce the escalation of disputes continues to grow, it is time for a land registration system through PTSL changed to positive land registration system.

Keywords : Government Policy; Legal Certainty of Land Rights; PTSL.

\section{Introduction}

The provisions in Article 33 paragraph (3) of the Act of 1945 states that: Earth, water and natural resources contained therein, controlled by the State and used for the greater prosperity of the people. ${ }^{3}$ Furthermore, the rights of control of State outlined in Act No. 5 of 1960 on Basic Regulation of Agrarian Rights mastered Country elaborated, Manages and organizes allocation, use, supply and maintenance of earth, water and air space, determine and regulate legal relations between people with the earth, water and air space, determine and regulate legal relations between the people and the legal acts concerning the earth, water and space.

Registration on plots carried out in order to obtain legal certainty for land-rights holders and other parties with an interest in the land. With the registration and get a certificate, holders of land rights have strong evidence on the ground. Basic Agrarian Law stipulates that the Government held land registration throughout the territory of the Republic of Indonesia which aims to ensure legal certainty over rights to land. ${ }^{4} \mathrm{As}$ stated also the function of the certificate in Article 19 paragraph (2) c of the BAL, therefore, anyone can easily prove himself as the holder of rights to land when it becomes clear name listed in the certificate. Furthermore, it can prove the

\footnotetext{
${ }^{1}$ Student of Master of Law, Universitas Islam Sultan Agung Semarang and Office of Agrarian Affairs and Spatial Planning / National Land Agency, email: sitsul.ss@gmail.com

${ }^{2}$ Faculty of Law Universitas Islam Sultan Agung

${ }^{3}$ Constitution of the Republic of Indonesia 1945, Article 33 paragraph (3)

${ }^{4}$ Urip Santoso, 2010, Hukum Agraria dan Hak-hak Atas Tanah, Jakarta: Prenada Media Group, Edition $6{ }^{\text {th }}$, p. 248.
} 
circumstances of the land area, for example, the boundaries, or anything related to the plot in question.

Certification ground in practice, sometimes there are vast differences in soil contained in the certificate with the factual conditions in the field. This is especially if the process of certification of the land done systemically (eg via Prona). It could happen that the land Certification carried out in the framework of sporadic land registration. According to Article 77 paragraph (1) of the Regulation of the State Minister of Agrarian Affairs / Head of National Land Agency No. 3 of 1997 on the Implementation of Government Regulation No. 24 of 1997 on Land Registration, measurement sporadic plot is basically the responsibility of the Head of the Land Office.

Systematic land registration was held on the initiative of the government is based on a long-term work plan and annual and implemented in areas designated by the State Minister of Agrarian Affairs / Head of National Land Agency. Systematic land registration preferred, because in this way speed up the acquisition of data on land parcels to be listed rather than through sporadic land registration.

Government organized Complete Systematic Land Registration (PTSL) which is a government policy in the area of land to facilitate land registration activities in Indonesia as an embodiment of the program Chess Conduct in the Field of Land, so the program certificate of land rights in bulk to ensuring legal certainty for the control and ownership of land as a sign of strong evidence.

\section{Research methods}

The method used in this research is the method of approach to socio-legal research, consisting of socio research and legal research. ${ }^{5}$ This study is a descriptive analysis. According Soerjono Soekanto descriptive is intended to provide the data as thoroughly as possible about the people, circumstances or other symptoms. ${ }^{6}$

Descriptive analytical research is a type of research to provide data as thoroughly as possible about a social phenomenon or phenomena that occur in the life of society by simply exposing the facts systematically, according to the needs of research. ${ }^{7}$ With this analytical descriptive study can easily figure out the problem (case) associated with the phenomenon or other symptoms associated with and explain the government policies to accelerate the legal certainty through PTSL Land Rights.

\section{Result and Discussion}

\subsection{Implementation PTSL In Kendal District Land Office}

\footnotetext{
${ }^{5}$ In the socio-legal research approach means that there are two aspects of the research. First, the legal aspects of the research, the research object persists in the form of law in the sense of "norm" of legislation, and secondly, socio research, which uses the method and theory of social sciences of the law to assist researchers in conducting the analysis, this approach, according Widhi Handoko, remain in the realm of law, just a different perspective. See, Zamroni, 1992, Pengembangan Pengantar Teori Sosial, Yogyakarta: Tiara Yoga, p. 80-81. See also in Widhi Handoko, Op Cit. p.28

6 Soerjono, Soekanto, Pengantar Penelitian Hukum, (Jakarta: UI Press, 1981), p.12.

${ }^{7}$ Mukti Fajar ND dan Yulianto Achmad, 2010, Dualisme Penelitian Hukum Normatif dan Empiris, Pustaka Pelajar, Yogyakarta, p. 53.
} 
Land Office is the agency of the Ministry of Agricultural and Spatial Planning / National Land Agency in Regency / City which is under and responsible to the Minister of ATR / BPN RI via the Head Office of the National Land Agency. Land Office is located in the district / municipality, which conducted registration of land rights and the maintenance of a public register of land registration.

Program of asset legalization strategy through PTSL activities financed by the state budget, the Head of BPN Regional Office of Central Java Province, Head of the Kendal District Land Office, and the coordinator and the executive PTSL prohibited from requesting, picking and or receive any fee in order to carry out land registration. Legalization of public assets through PTSL based targets set PTSL activities of each fiscal year in accordance with the budget allocation received by the Ministry of Agricultural and Spatial Planning / National Land Agency. In order to plan the establishment of subject and object legalization programs as well as community assets through PTSL in order to meet the target completion on time and on target,

It also formed the coordinating team activities and schedule the activities PTSL. Head of the Land Office PTSL carry out activities ranging from planning to handover certificate of land rights. In order to carry out this task the Head of the Kendal District Land Office assisted by:

- Head of Sub Division of Administration has the task of granting administrative support to all organizational units of the Land Office;

- Section Chief of Land Infrastructure has the task of coordinating and implementing measurement and basic mapping, measurement and cadastral mapping, and surveying and thematic mapping;

- Relations Section Chief Land Law has the task of coordinating and implementing the determination of land rights and empowerment of community land rights, land rights registration and maintenance of data and guidance PPAT land rights;

- Land Planning Section Chief has the task of coordinating and implementing stewardship of land and certain regions, land reform and land consolidation;

- Head of Land Acquisition Section has the task of coordinating and implementing the use of government land and land assessment, and to facilitate the procurement and establishment of government land;

- Head of Section Troubleshooting and Land Management has the task of coordinating and implementing the handling of disputes, conflicts and land matters, and control of land.

Head of the Land Office to coordinate overall and assign other tasks as appropriate for the implementation of activities PTSL. In accordance with the targets of the President in 2017 to PTSL of 5 million field throughout Indonesia, with respect to the Kendal District Land Office acquire a target of 12,500 for the first phase of the field, while for the second phase of 3,000 fields.

PTSL implementation is done in phases:

- Planning and preparation;

- The stipulation PTSL activities;

- The formation and establishment of the Adjudication Committee PTSL;

- Counseling;

- Physical Data Collection and Data Juridical plot; 
- Edaphology;

- Physical data and data announcement Juridical plot as well as verification of entitlements;

- Issuance of the decision to grant or recognition of right to land;

- Bookkeeping and issuance of Certificate of Land Rights;

Determination of the location of objects PTSL done carefully and thoroughly in accordance with predetermined criteria PTSL. The stipulation PTSL activities should consider the results of the program land in Kendal District Land Office in the previous year.

Head of the Land Office set PTSL activity locations in the working area, location determination can be made in one area of the village / village or gradually piece by piece in a single stretch. Location determination is done with the following provisions: based on availability of a special budget PTSL have been allocated in APBN / APBD; prioritized on the location of villages / subdistricts activities PRONA / PRODA, village funds, cross-sector, non-governmental mass, corporate social responsibility (CSR) and / or other mass land registration programs, or based on the availability of funds authorized in accordance with the provisions of laws an invitation for one (1) rural / urban PTSL; considering the availability of map work, availability and optimal capability PTSL executing on each of the Land Office.

In accordance with the targets of the President in 2017 to PTSL of 5 million field throughout Indonesia, with respect to the Kendal District Land Office acquire a target of 12,500 for the first phase of the field, while for the second phase of 3,000 fields.

\subsection{Government Policies Accelerate the Legal Certainty In Landrights Through PTSL}

Position The Constitution of 1945 as a legal norm occupy top notch, he also has control functions, whether any laws and regulations including the BAL as lower product in law or not in accordance with the provisions of the Constitution 1945. If viewed from the perspective of Constitutional Law countries, both in terms of procedures for its formation, as well as from the point of the material in the rules further implement the higher provisions, then there is no reason to doubt its validity as an organic law. ${ }^{8}$

Relations Act of 1945, article 33, paragraph 3 of the maximum restrictions on the ownership of land, in this land of non-agricultural property in the BAL can be seen in Article 2, paragraph 3 of the BAL which describes the authority of which is based on the right to control the State, namely: ${ }^{9}$

First, Arranging and conducting, allocation, use, inventory, and maintenance of the earth, the water and the space;

Second, Determine and regulate legal relations between people with the earth, water and air space;

Third, Determine and regulate legal relations between persons and legal acts concerning the earth, water, and space. The 1945 Constitution is the legal basis of land, while the BAL as the implementation of Article 33 of the 1945 Constitution is one of

\footnotetext{
${ }^{8}$ Arie S. Hutagalung, 2005, Tebaran Pemikiran Seputar Masalah Hukum, (Jakarta: Lembaga Pemberdayaan Hukum Indonesia, p. 10

${ }^{9}$ Basic Agrarian Act No. 5of 1960, article 2.
} 
the things taken for granted, because Article 33 paragraph 3 of its mainly the main legal basis of the law of the land (Agrarian Law). The same provision is also contained in Article 38 of the 1950 Constitution which reads: ${ }^{10}$

"Earth, water, and natural riches contained therein, controlled by the State and used for the greater prosperity of the people"

Elucidation of Article 33 of the Constitution provides as follows: Article 33 is listed on economic democracy, production is done by all, for all under the direction or viewing the member-member community, communities preferred prosperity, not the individual prosperity. Because the economy is structured as a joint venture based on family principles. Waking up in accordance with the company which is the cooperative. Economy is on the basis of democracy, prosperity for all people. Because the production branches which are important for the State and the master of life must be controlled by the State. Otherwise, the reins of production into the hands of those people in power and the people at large will be oppressed. Only companies that dominate the life of many people may be in the hands of one. Earth and water and natural resources contained within the earth are the subjects of prosperity of the people. It should be controlled by the State and used for the greatest prosperity of the people. The discovery of the law is a law-making process by legal officers who are assigned the task of implementing the law to those events which concrete law. ${ }^{11}$ This is a process of concretization and individualization of common law rules to remember the events of the concrete. Or more continued to say that legal discovery is the process of concretization or individualization of legal regulation (das sollen) which is common to remember the events of concrete (das sein) specific. Legal discovery is mainly done by the judge in examining and deciding a case, the invention is considered law by judges who have the authority. ${ }^{12}$

Based on strategic program priorities of the Ministry of Agrarian and Spatial Planning / National Land Agency (ATR / BPN), the Ministry of ATR / BPN, held a full systematic land registration program (PTSL).

Complete Systematic Land Registry implemented for all objects Land Registration in the entire territory of the Republic of Indonesia. Land Registry places referred to include the entire plot without exception, both parcels of land rights, land asset / regional government, the land of the State Owned Enterprises / Regional Owned Enterprises, the village land, State land, the land of indigenous and tribal peoples, forest, land reform object, land resettlement, and other parcels.

Implementation of the registration certificate of land rights through activities PTSL in the Kendal District Land Office, implemented through land registration activities for the first time carried out simultaneously for all objects of registration of land in the entire territory of the Republic of Indonesia in the territory of the village / village or other names that level with the, which involves the collection and determination of the truth of physical data and juridical data regarding one or more objects Land Registry for

\footnotetext{
10 Ibid, p. 11

${ }^{11}$ Sudikno Mertokusumo dan A. Pitlo. 1993 Bab-bab tentang Penemuan Hukum, Citra Aditya Bandung., p. 4.

12 Ibid, p. 5
} 
registration purposes. PTSL is an activity organized by the government in the land sector in general and in the field of registration of land rights in particular.

Acceleration of land registration with PTSL method is the implementation of the mandate of Article 33 A paragraph (3) of the 1945 Constitution and Articles 2 and 19 of Act No. 5 of 1960. Application of the method PTSL, an acceleration path so that in 2025 the entire plot in Indonesia registered. Implementing the PTSL implementation is expected to meet all the quality in terms of principles, principles, and methodologies nothing is missed. In addition PTSL an acceleration of business as usual method, which is already implemented.

Land law policy on legal certainty system Ownership Rights on Land that exceeds this maximum, not a work of art that is the only to be enjoyed by those who observe it. He is also not a result of culture (although BAL derived from customary law) that the material only to be logically rational assessment. Laws are created to run. "Law that was never executed, essentially has ceased to be legal", according Satjitpto Rahardjo quoted Scholten. Then in giving an explanation of the land laws, especially regarding the implementation of land policy in the field of legal certainty of land ownership, researchers can give the following explanation: ${ }^{13}$

Policy of land law system certificate of registration of land rights through this PTSL, not a work of art that is the only to be enjoyed by those who observe it. He is also not a result of culture (although BAL derived from customary law) that the material only to be logically rational assessment.

The purpose of law is not only justice, but also of legal certainty and expediency. The fulfillment of justice in a legislation does not yet enough because it still needs the requirements of legal certainty. Legal certainty will be achieved if a rule were vague, so it does not give rise to different interpretations and there is no overlap between the existing regulations, both vertically and horizontally. Creating a legal system that will either be a difficult thing when the substance of the underlying rules are confusion due to discrepancies in the existing rules. ${ }^{14}$

\section{Closing}

\subsection{Conclusion}

Based on the above it can be some conclusions, namely:

- Implementation PTSL in Kendal District Land Office begins with a systematic planning PTSL activities by the Head of the Kendal District Land Office with pre inventory candidate and potential participants. PTSL activities intended for all land in Indonesia are owned individually as well as a legal entity. PTSL implemented several programs, including determination of the adjudication committee PTSL, extension then the process Certification Landrights, followed by a ground inspection process that includes physical data and juridical announcement of the plot along with proof of the rights and ends with the issuance of the Decision to Grant Rights

13 Loc Cit; Widhi Handoko, Bekerjanya Hukum dalam Masyarakat, Http://Widhihandoko.Com/WpAdmin/Bekerjanyahukumdalammasyarakat, Accessed on Saturday, October 12, 2018.

${ }^{14}$ Ibid., p. 181 
to Land.

- The government's policy to accelerate the legal certainty of land rights through PTSL is base in Kendal land that already has a certificate covering an area of 13834.46 hectares. Number of parcels that have not been certified at 281126 fields. The total area of land that has been recently certified 53.73 percent of the total plots of land in Kendal. So that should be the policy of the government in this case the Ministry of Agricultural and Spatial Planning / National Land Agency (ATR / BPN), the Ministry of ATR / BPN, held a full systematic land registration program (PTSL). Certificate of registration of land rights through PTSL activities, carried out through land registration was first systematically. Certificate of land rights through PTSL activities undertaken to create legal certainty on plots in Indonesia.

\subsection{Suggestion}

- For the community, it should to register their land to the local Land Office in order to secure their rights over the land it controls through a Systematic Land Registration Complete (PTSL).

- For the government, in accordance with the purpose of land registration is to provide certainty and legal protection to the rights holder, to reduce the escalation of disputes continues to grow, it is time for a land registration system through PTSL changed to positive land registration system by: 1) .percepatan land registration full systematically from village to village to the ground plane in the entire territory of the Republic of Indonesia registered; 2). improve record keeping systems based on information technology and communication, 3). holding fund insurance institution, as a guarantor if the contested land rights certificates, so that the certificate will have absolute proof strength after five (5) years issued can no longer be contested.

\section{Bibliography}

\section{Books}

[1] Arie S. Hutagalung, 2005, Tebaran Pemikiran Seputar Masalah Hukum, Lembaga Pemberdayaan Hukum Indaonesia, Jakarta.

[2] Djuhaedah Hasan, 1996, Lembaga Jaminan Kebendaan Bagi Tanah dan Benda lain yang melekat Pada Tanah Dalam Konsepsi Penerapan Atas Pemisahan Horisontal, PT.Citra Aditya Bakti, Bandung.

[3] Fx Adji Samekto, 2013, Hukum Dalam Lintasan Sejarah, Indepth Publishing, Semarang.

[4] Joyo Winoto, 2007, Reforma Argaria dan Keadilan Sosial, BPN RI, Bogor.

[5] Mukti Fajar ND dan Yulianto Achmad, 2010, Dualisme Penelitian Hukum Normatif dan Empiris, Pustaka Pelajar, Yogyakarta.

[6] Satjipto Rahardjo, 1980, Hukum dan Masyarakat, Angkasa, Bandung.

[7] Soerjono Soekanto, 1981, Pengantar Penelitian Hukum, UI Press, Jakarta.

[8] Sujono Wignjodipuro, 1982, Pengantar dan Asas-Asas Hukum Adat, Gunung Agung, Jakarta. 
[9] Urip Santoso, 2010, Hukum Agraria dan Hak-hak Atas Tanah, Prenada Media Group, cetakan ke-6, Jakarta.

[10] Widhi Handoko, 2010, Rekonstruksi Kebijakan Hukum Pertanahan Berbasis Nilai Keadilan Sosial" (Studi Tentang Stelsel Publisitas Negatif Berunsur Positif Pada Sistem Birokrasi dan Pelayanan Publik Badan Pertanahan Nasional), Desertasi Program Doktoral Ilmu Hukum, Undip, Semarang.

\section{Legislation}

[1] Constitution of the Republic of Indonesia 1945

[2] Book of Civil Code (BW)

[3] Law of the Republic of Indonesia Number 5 of 1960 on Basic Regulation of Agrarian Affairs;

[4] Law of the Republic of Indonesia Number 25 of 2009 on Public Service;

[5] Presidential Decree No. 34 of 2003 on National Policy on Land Affairs;

[6] Presidential Regulation No. 63 of 2013 concerning the National Land Agency;

[7] Regulation of the Minister of Agrarian and Spatial Planning / Head of National Land Agency of the Republic of Indonesia Number 12 of 2017 on the Acceleration of Systematic Land Registration Complete;

[8] Local Government and relevant agencies regarding of PTSL.

\section{Website / Internet}

[1] Widhi Handoko, Bekerjanya Hukum dalam Masyarakat, http://Widhihandoko.Com/Wp-Admin/Bekerjanyahukumdalammasyarakat.

[2] Widhi Handoko, http: // widhihandoko. Com / content / uploads / 2016 / 04 / MENGHADAPIDINAMIKA.pdf.

[3] Widhi Handoko, http://lapatuju.blogspot.com/2013/03/keadilan-kemanfaatandankepastian.html. 